\title{
ROLE PLAYING DALAM PEMBELAJARAN PENDIDIKAN PANCASILA DAN KEWARGANEGARAAN
}

\author{
T Heru Nurgiansah ${ }^{1 *}$, Hendri², Cep Miftah Khoerudin ${ }^{3}$ \\ 1) Universitas PGRI Yogyakarta, Yogyakarta, Indonesia \\ 2) Universitas Pamulang, Tangerang Banten, Indonesia \\ 3) Universitas Pasundan, Jawa Barat, Indonesia \\ *nurgiansah@upy.ac.id
}

\begin{abstract}
The majority of students consider the subjects of Pancasila and Citizenship Education to be boring subjects. The content of many materials, monotonous media and learning models, until the teacher's ability in classroom management is signalled to be the cause that results in less motivation, activeness, and student achievement. A proper learning model is needed to overcome these learning problems, namely role-playing learning models. The purpose of this study was to see the phenomenon of learning Pancasila and Citizenship Education in Class X SMA PGRI 1 Kasihan Bantul. The research method used is the qualitative method with descriptive studies. Data collection techniques in the form of observations, interviews, and documentation. The results showed that the use of Role-Playing learning models succeeded in making the learning atmosphere more interesting, active, and successful in improving students' academic abilities, especially in the material of the National Legal and Judicial System.
\end{abstract}

Keywords: role playing, learning, pancasila and citizenship education

\begin{abstract}
Abstrak
Mayoritas siswa menganggap mata pelajaran Pendidikan Pancasila dan Kewarganegaraan adalah mata pelajaran yang membosankan. Isi materi yang banyak, media dan model pembelajaran yang monoton, sampai kemampuan guru dalam pengelolaan kelas disinyalir menjadi penyebabnya yang mengakibatkan motivasi, keaktifan, dan prestasi siswa menjadi kurang. Diperlukan sebuah model pembelajaran yang tepat untuk mengatasi permasalahan belajar tersebut, yakni model pembelajaran Role Playing. Tujuan penelitian ini adalah untuk melihat fenomena pembelajaran Pendidikan Pancasila dan Kewarganegaraan di Kelas X SMA PGRI 1 Kasihan Bantul. Metode penelitian yang digunakan adalah metode kualitatif dengan studi deskriptif. Teknik pengumpulan data berupa observasi, wawancara, dan dokumentasi. Hasil penelitian menunjukan bahwa penggunaan model pembelajaran Role Playing berhasil membuat suasana pembelajaran semakin menarik, aktif, dan berhasil meningkatkan kemampuan akademik siswa khususnya pada materi Sistem Hukum dan Peradilan Nasional.
\end{abstract}

Kata kunci: role playing, pembelajaran, pendidikan pancasila dan kewarganegaraan 


\section{PENDAHULUAN}

Kualitas pembelajaran yang baik merupakan dambaan semua pihak, baik pemerintah maupun warga sekolah. Pendidikan seyogyanya diarahkan pada peningkatan kualitas pembelajaran (Kusnadi, Martini, \& Nugraha, 2017). Kualitas pembelajaran yang baik akan menghasilkan sesuatu yang baik pula. Peningkatan kualitas pembelajaran dimulai dari hal terkecil terlebih dahulu seperti pelaksanaan pembelajaran di kelas yang optimal sehingga menghasilkan siswa siswi yang cerdas dan dapat menyelesaikan segala persoalan yang terjadi. Pendidikan ibarat wadah untuk membentuk warga negara yang cerdas (Dewantara \& Nurgiansah, 2021).

Pembelajaran adalah proses interaksi antara peserta didik, guru dan lingkungan belajar (Hanum, 2020). Berbagai usaha sudah dilakukan pemerintah untuk meningkatkan mutu dan kualitas pembelajaran. Usaha pemerintah dalam memajukan pendidikan diantaranya pemberian beasiswa bagi masyarakat berprestasi dan kurang mampu, mengadakan tutorial dan pelatihan bagi guru-guru untuk meningkatkan kompetensinya, dan memperbaiki sarana prasarana sebagai penunjang pembelajaran karena infrastruktur yang semakin baik akan menghasilkan pembelajaran yang baik. Pembelajaran yang baik bukan dilihat dari seberapa lama kita belajar dan seberapa banyak ilmu yang kita dapat. Memang belajar itu sepanjang hayat namun esensi dari slogan itu adalah kebermanfaatan yang didapat dari proses belajar tadi. Teori tabularasa misalnya mengatakan bahwa anak itu ibarat kertas putih yang kosong, ketika anak tersebut belajar maka kertas tersebut menjadi penuh coretan bermakna. Coretan-coretan tersebut memberikan manfaat baik bagi dirinya sendiri maupun bagi orang lain.

Dari ketiga contoh usaha pemerintah di atas, satu hal yang paling disorot adalah peningkatan kemampuan dan kompetensi guru. Hal tersebut diantaranya pengelolaan kelas, penyampaian materi ajar, dan penggunaan model pembelajaran. Guru memiliki multi tugas seperti sebagai pengajar, pembimbing, dan pelatih. Dari hasil observasi awal di Sekolah Menengah Atas PGRI 1 Kasihan Bantul, didapat fakta bahwa guru Pendidikan Pancasila dan Kewarganegaraan jarang menggunakan model pembelajaran interaktif karena kebanyakan menggunakan metode ceramah atau presentasi kelompok. Padahal seorang guru dituntut untuk mempunyai kemampuan menggunakan beragam model pembelajaran. Kemampuan dan kemauan guru untuk mahir dalam penggunaan berbagai model pembelajaran aktif masih kurang (Nurgiansah \& Pringgowijoyo, 2020).

Selain itu, fungsi utama guru harus bisa menilai karakteristik dari siswanya yang nantinya akan memberikan gambaran model pembelajaran yang dapat digunakan. Guru harus mampu memahami beberapa hal dari peserta didik seperti kemampuan, potensi, minat, hobi, sikap, kepribadian (Nurgiansah \& Sukmawati, 2020). Hal tersebut dapat diperoleh jika guru mempunyai kompetensi kepribadian dan kompetensi sosial. Selain itu seorang guru diharapkan mampu untuk bersikap fleksibel dalam menghadapi situasi kondisi terkini (Nurgiansah, 2021a). Guru sebagai pengelola pembelajaran hendaknya mampu memilih dan menentukan model, metode, maupun media dalam menjalankan pembelajaran di kelasnya (Fitasari, Tohari, \& Praptiningsih, 2015). Oleh sebab itu, seorang guru dituntut untuk bisa berbicara di depan kelas dan menjadi public speaking yang handal (Nurgiansah, 2020).

Selain menitikberatkan pada permasalahan guru, yang tak kalah pentingnya adalah perilaku siswa dalam pembelajaran. Banyak masalah yang dihadapi siswa di kelas, seperti 
kehilangan motivasi belajar dikarenakan tidak menyukai mata pelajaran tertentu, rendahnya partisipasi di kelas karena tidak mengerti terhadap materi yang disampaikan oleh guru, sampai jebloknya prestasi akademik siswa yang dipengaruhi rasa malas belajar dan membaca. Motivasi belajar adalah dorongan internal dan eksternal pada siswa-siswa yang sedang belajar untuk mengadakan perubahan tingkah laku (Wibawa \& Suarjana, 2019).

Pelaksanaan pembelajaran harus memperhatikan bakat dan minat siswa sehingga siswa akan antusias terhadap semua mata pelajaran yang diajarkan di sekolah (Setiawan, 2014). Terlebih pada mata pelajaran Pendidikan Pancasila dan kewarganegaraan yang isi materinya banyak dan menimbulkan rasa bosan. Tantangan dunia pendidikan saat ini yaitu menerapkan sistem pendidikan yang memungkinkan optimalisasi seluruh pihak, baik guru, siswa, maupun pemerintah (Gani, 2018). Dengan begitu, permasalahan pendidikan menjadi tanggung jawab semua pihak yang terlibat dalam dunia pendidikan.

Persoalan-persoalan yang dihadapi siswa di kelas harus menjadi fokus utama seorang guru agar permasalahan tersebut bisa diselesaikan dengan jalan keluar yang tepat, cepat dan efisien yang salah satunya adalah dengan menggunakan model pembelajaran Role Playing atau bermain peran. Metode role playing atau dikenal dengan bermain peran merupakan salah satu bentuk drama. Dalam metode ini, siswa diminta untuk bermain suatu drama, secara spontan untuk memperagakan peran-perannya dalam berinteraksi. Peran yang dilakukan berhubungan dengan masalah maupun tantangan dan hubungannya dengan manusia.

Metode bermain peran merupakan suatu metode pembelajaran, di mana subjek diminta untuk berpura-pura menjadi seseorang dengan profesi tertentu yang digeluti orang tersebut. Selain itu, subjek juga diminta untuk berpikir seperti orang tersebut agar dia dapat mempelajari tentang bagaimana menjadi seseorang dengan profesi tersebut. Dalam penelitian ini, siswa akan berperan sebagai aparat penegak hukum yang terdiri dari kepolisian, kejaksaan, hakim, pengacara, pelaku dan korban.

Dari berbagai peran tersebut terdapat pada materi sistem hukum dan peradilan. Penelitian ini selain bertujuan untuk melihat partisipasi dan keaktifan siswa dalam belajar, juga untuk mengenalkan kepada siswa mengenai aturan hukum yang ada di negara Indonesia. Pemahaman siswa terhadap hukum perlu ditingkatkan agar menjadi warga negara yang baik, berpartisipasi dan berguna bagi masyarakat, bangsa, dan negara.

\section{METODE PENELITIAN}

Penelitian ini menggunakan metode kualitatif dengan pendekatan studi deskriptif. Penelitian dilaksanakan di kelas X SMA PGRI 1 Kasihan Bantul Yogyakarta yang berjumlah 30 orang siswa. Pengumpulan data menggunakan observasi, wawancara, dan dokumentasi. Observasi dilaksanakan pada saat mata pelajaran Pendidikan Pancasila dan Kewarganegaraan berlangsung. Observasi berarti pengamatan secara langsung di lokasi penelitian (Nurgiansah, 2021b). Wawancara dilakukan terhadap guru Pendidikan Pancasila dan Kewarganegaraan dan sebagian siswa kelas X. Dokumentasi dilakukan sebagai arsip agar data yang telah diperoleh tidak hilang maknanya. Penelitian ini dilaksanakan pada materi Sistem Hukum dan Peradilan Nasional. Tahapan penelitian terdiri dari penyampaian materi, menentukan kasus tindak pidana, dan praktek peradilan semu. Penelitian ini bertujuan untuk melihat gambaran pembelajaran Pendidikan 
Pancasila dan Kewarganegaraan dengan menggunakan model pembelajaran Role Playing. Validasi data dilakukan oleh peneliti melalui pengamatan langsung di dalam kelas dengan melakukan pengukuran tingkat partisipasi dan keaktifan siswa sebelum menggunakan model Role Playing dan sesudahnya. Selain itu, untuk memastikan keberhasilan penelitian, peneliti mewawancarai guru dan sebagian siswa yang terlibat dalam pembelajaran.

\section{HASIL DAN PEMBAHASAN}

Pelaksanaan penelitian dilaksanakan di hari selasa mulai pukul $07.00 \mathrm{~s} / \mathrm{d} 08.30$ WIB. Penelitian dengan penggunaan Role Playing ini dilakukan selama dua kali pertemuan, dimana pertemuan pertama penyampaian materi dan langkah-langkah model pembelajaran Role Playing. Dan pertemuan kedua adalah praktek peradilan semu. Pembelajaran pertemuan pertama berjalan sebagaimana mestinya. Pembelajaran diawali kegiatan apersepsi yang terdiri dari guru mengucapkan salam, menanyakan kabar, mengabsen siswa, dan menyampaikan indikator atau tujuan pembelajaran. Kegiatan tersebut berlangsung selama 10 menit yang kemudian dilanjutkan pada kegiatan inti selama 60 menit. Kegiatan inti ini terdiri dari penyampaian isi materi mengenai sistem hukum dan peradilan nasional, diantaranya pengertian hukum menurut para ahli, macammacam hukum, lembaga peradilan, dan kasus pelanggaran hukum. Selepas itu kegiatan penutup selama 20 menit yang diisi dengan tes tulis untuk mengukur pengetahuan siswa mengenai materi yang telah disampaikan, dan penjelasan penggunaan model pembelajaran Role Playing yang akan dipraktekan minggu depan. Adapun kasus yang akan diperankan adalah penganiayaan asisten rumah tangga.

Pada pembelajaran pertemuan pertama tersebut, siswa belum terlihat partisipasi dan motivasinya. Guru masih terlihat mendominasi pembelajaran. Siswa hanya mendengarkan dan sesekali bertanya disertai senda gurau. Begitu juga dalam prestasi belajar, siswa masih banyak yang salah menjawab pertanyaan diakhir pembelajaran. Hal ini membuktikan bahwa tanpa menggunakan model pembelajaran tertentu, maka permasalahan siswa seperti motivasi, keaktifan, dan prestasi belajar tidak dapat diselesaikan dengan baik. Berawal dari masalah tersebut, maka pada pertemuan kedua, siswa akan bermain peran dalam kasus pelanggaran hukum. Siswa terbagi kedalam menjadi 2 kelompok masing-masing 15 orang dengan beberapa peran, diantaranya: 3 siswa menjadi hakim, 1 siswa menjadi panitera, 4 siswa menjadi penyidik kepolisian, 2 orang siswa menjadi saksi, 1 orang tersangka sekaligus terdakwa, 1 pengacara atau kuasa hukum, 1 jaksa penuntut umum, 1 orang korban serta 1 orang menjadi dokumenter.

Kegiatan dimulai saat korban dianiaya oleh tersangka dan dilihat oleh 4 orang siswa sebagai saksi, 2 siswa menjadi saksi yang meringankan di pengadilan, dan 2 siswa lagi menjadi saksi yang memberatkan. Lalu korban melaporkan ke kepolisian yang selanjutnya menangkap tersangka dan melakukan penyidikan serta memeriksa saksi dan melakukan rekonstruksi. Setelah berkas lengkap dan siap, tersangka pun menjalani proses persidangan yang di dalamnya terdapat penyampaian materi ajar yang berkenaan dengan sistem hukum dan peradilan nasional. 
Gambar 1. Rekonstruksi

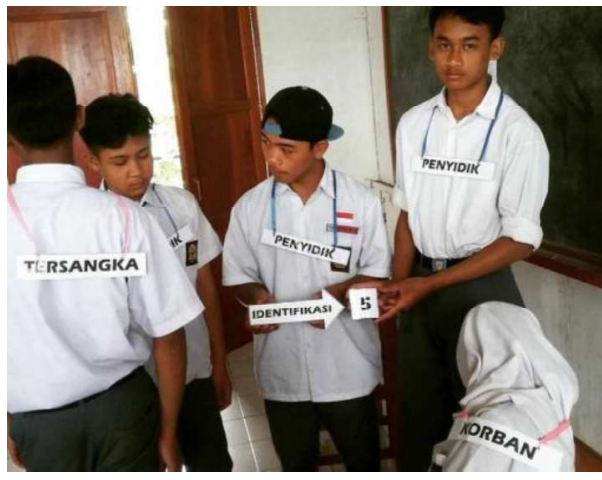

Adapun tahapan persidangan terdiri dari: (1) pembacaan dakwaan oleh majelis hakim terhadap terdakwa, di dalamnya disampaikan pasal yang dikenakan. (2) pembacaan eksepsi atau pembelaan terdakwa terhadap tuntutan hakim. Dalam hal ini terdakwa punya dua pilihan, yakni mengakui ataupun mengelak. (3) tahapan pembuktian dengan pemeriksaan saksi-saksi yang menyampaikan kronologis kejadian. (4) pembacaan tuntutan mengenai berapa lama vonis terdakwa (5) pledoi atau pembelaan dari terdakwa (6) jatuhnya vonis hakim yang berkekuatan hukum tetap.

Pelaksanaan pembelajaran pada tahap dua berbeda jauh dengan pelaksanaan pembelajaran tahap pertama. Kali ini siswa memegang kendali pembelajaran, guru hanya memantau dan sesekali mengarahkan atau mengklarifikasi materi ajar. Siswa sangat antusias. Keaktifan dan motivasi belajar siswa meningkat pesat. Begitu juga dengan prestasi belajarnya pun meningkat. Hal ini dibuktikan dengan evaluasi berupa tes diakhir simulasi persidangan bahwa sebagian besar siswa dapat menjawab pertanyaan, hal ini berbanding terbalik saat pertemuan pertama saat materi disampaikan secara ceramah oleh guru.

Berdasarkan pelaksanaan model pembelajaran Role Playing tersebut, dapat diketahui kelebihan dan kekurangannya serta kendala dan solusi agar pembelajaran kedepannya lebih baik lagi. Adapun kelebihan dari model pembelajaran ini adalah: (1) siswa memegang kendali pembelajaran/sangat dominan. (2) materi yang didapat mudah untuk diingat karena siswa terlibat langsung di dalamnya. (3) mampu menarik minat belajar siswa, partisipasi siswa, motivasi siswa, dan meningkatkan pemahaman terhadap isi materi.

Gambar 2. Jalannya Persidangan
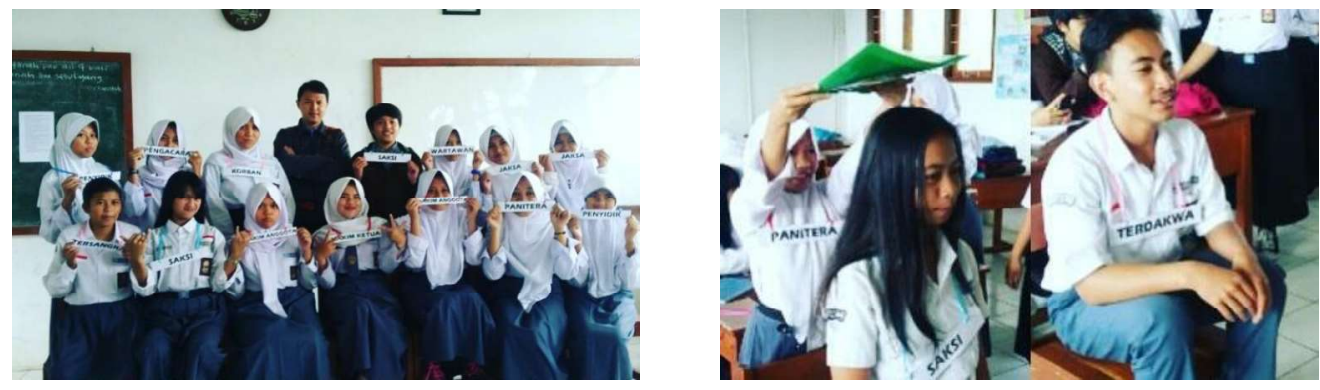
Meskipun begitu, model ini memiliki kekurangan, diantaranya: (1) memerlukan waktu yang lama untuk mensimulasikan materi bahkan bisa lebih dari 1 kali pertemuan (2) sangat mementingkan kreativitas dan daya nalar siswa yang tinggi sehingga mengakibatkan sebagian siswa menjadi down dan tidak mau terlibat dalam pembelajaran (3) tidak semua materi dan tidak semua mata pelajaran dapat menggunakan model pembelajaran ini.

Kendala yang dihadapi dalam pembelajaran Pendidikan Pancasila dan Kewarganegaraan dengan model pembelajaran Role Playing, diantaranya: (1) siswa nampak kebingungan diawal simulasi terutama kelompok 1 dikarenakan ini pertama kalinya siswa menggunakan model pembelajaran Role Playing. Untuk menghindari kejadian serupa, guru harus selalu menggunakan beragam model pembelajaran. Guru harus mempertimbangkan agar menggunakan media pembelajaran untuk meningkatkan hasil belajar siswa (Niska \& Gregorius, 2013). (2) kelas menjadi gaduh namun tetap kondusif dikarenakan antusiasme siswa yang terlampau tinggi. Dengan begitu guru diharapkan mampu untuk mengelola kelas untuk menjaga kondusifitas dalam pembelajaran. (3) tidak cukup waktu untuk kelompok kedua dikarenakan kelompok pertama melebihi batas waktu yang telah diberikan. Hal ini wajar terjadi karena pada pelaksanaan pertama kali akan menghabiskan banyak waktu untuk beradaptasi.

Penelitian mengenai model pembelajaran Role Playing telah banyak dilakukan berbagai kalangan, baik itu guru dalam Penelitian Tindakan Kelas, maupun oleh mahasiswa dalam menyelesaikan skripsinya. Namun pada penelitian ini terdapat pembaruan diantaranya pembuatan dan penggunaan name tag yang menarik sehingga berhasil menstimulus minat belajar siswa jauh sebelum melaksanakan praktek. Di masa yang akan datang, peneliti bisa berimprovisasi lagi misalkan dengan penggunaan seragam sungguhan dan rekonstruksinya dilakukan di luar ruang kelas dengan kasus yang lebih rumit lagi seperti pencurian kendaraan roda dua, pembunuhan berencana, atau pencurian dengan pemberatan.

Model Role Playing merupakan model pembelajaran yang digagas untuk menghasilkan siswa yang turut berpartisipasi secara langsung. Model ini merupakan satu dari sekian banyak model pembelajaran interaktif. Model ini biasanya digunakan pada mata pelajaran Bahasa Indonesia karena art Role Playing ini artinya bermain peran. Permainan peran lebih banyak digunakan dalam materi drama. Namun pembaharuan dari artikel ini menunjukan bahwa model pembelajaran Role Playing ini dapat digunakan pada mata pelajaran Pendidikan Kewarganegaraan yang tentu saja disesuaikan dengan materi ajar. Penggunan model dan media pembelajaran dapat menembus ruang dan waktu yang berarti keluwesan dan fleksibilitas dalam kegiatan belajar dapat optimal (Nurgiansah, 2019).

Mata pelajaran Pendidikan Kewarganegaraan juga mempunyai karakteristik berbeda dibandingkan dengan mata pelajaran lain. Mata pelajaran ini merupakan multidisiplin ilmu karena didalamnya mencakup beberapa materi seperti hukum, politik, pemerintahan, sosial dan budaya. Pendidikan Pancasila juga bisa diasumsikan sebagai pendidikan hukum, pendidikan politik, dan pendidikan nilai moral. Pendidikan Kewarganegaraan dipandang sebagai mata pelajaran atau mata kuliah yang bertujuan untuk mempersiapkan warga negara agar mampu berpartisipasi (Telaumbanua, 2019). Pembelajaran Pendidikan Kewarganegaraan yang konten materinya mayoritas hafalan membawa kecenderungan para guru untuk terjebak pada metode belajar ceramah karena 
guru tidak mau mencoba menggunakan beragam model pembelajaran yang menarik (Saffudin, 2013).

Partisipasi siswa dalam kegiatan belajar sangat penting karena belajar adalah proses transformasi pengetahuan secara dua arah antara guru dan siswa. Dengan pembelajaran dua arah maka suasana belajar di kelas menjadi lebih hidup dan materi yang dicerna oleh siswa lebih maksimal. Partisipasi merupakan kekuatan yang dimiliki oleh masyarakat dapat mengatasi persoalan termasuk dalam mengatasi persoalan pembelajaran di bidang pendidikan (Rachman \& Fitra, 2020). Kedepan guru diharapkan lebih sering menggunakan beragam model dan media pembelajaran untuk mengatasi segala persoalan belajar di dalam kelas. Penyelesaian permasalahan belajar tidak selalu dengan Penelitian Tindakan Kelas, dapat juga melalui bimbingan konseling atau kegiatan eksperimen lainnya.

\section{SIMPULAN}

Penggunaan model pembelajaran Role Playing dalam pembelajaran Pendidikan Pancasila dan Kewarganegaraan di kelas X SMA PGRI 1 Kasihan Bantul pada materi Sistem Hukum dan Peradilan Nasional telah berhasil membuat kegiatan belajar mengajar menjadi menarik dan atraktif. Hal ini dibuktikan dengan antusiasme, motivasi, dan partisipasi siswa dalam kegiatan pembelajaran yang lebih baik dibandingkan dengan pembelajaran tanpa menggunakan model pembelajaran Role Playing. Peran guru dalam pembelajaran tidak lagi mendominasi sehingga siswa merasa dilibatkan dalam pembelajaran, dimulai dari pemilihan kasus, pembuatan media karton, sampai praktik peradilan semu.

\section{UCAPAN TERIMA KASIH}

Terima kasih kepada semua pihak yang telah terlibat dalam penelitian ini, diantaranya Kepala SMA PGRI 1 Kasihan Bantul Yogyakarta, Guru Pendidikan Pancasila dan Kewarganegaraan SMA PGRI 1 Kasihan dan Siswa Siswi Kelas X SMA PGRI 1 Kasihan. Terima kasih kepada Lembaga Penelitian dan Pengabdian Masyarakat Universitas PGRI Yogyakarta yang telah mendukung dan memfasilitasi kegiatan penelitian ini.

\section{DAFTAR PUSTAKA}

Dewantara, J. A., \& Nurgiansah, T. H. (2021). Efektivitas Pembelajaran Daring di Masa Covid-19 Bagi Mahasiswa Universitas PGRI Yogyakarta. Jurnal Basicedu: Research \& Learning in Elementary Education, 5(1), 367-375. https://doi.org/10.31004/basicedu.v5i1.669

Fitasari, D. N., Tohari, M., \& Praptiningsih. (2015). Pengaruh Penggunaan Media Video pembelajaran Terhadap Minat Belajar Mata Pelajaran Pendidikan Kewarganegaraan Siswa Kelas IX MTs NU Ungaran. Jurnal Wasdapa UNDARIS, $3(1), 55-67$. 
Gani, A. A. (2018). Interaksi Antara Pemanfaatan Media Pembelajaran Dan Gaya Belajar Terhadap Hasil Belajar IPS Terpadu. CIVICUS: Pendidikan-PenelitianPengabdian Pendidikan Pancasila dan Kewarganegaraan, 6(2), 83-87. https://doi.org/10.31764/civicus.v6i2.677

Hanum, F. F. (2020). Konseptual Pemanfaatan Model Media Web Moodle Dalam Pembelajaran PPKN Di Sekolah Menegah Atas. Jurnal Kewarganegaraan, 17(1), 1-10. https://doi.org/10.24114/jk.v17i1.18700

Kusnadi, E., Martini, E., \& Nugraha, G. N. (2017). Konstruk Pembelajaran Pendidikan Kewarganegaraan Berbasis Masalah Untuk Meningkatkan Kemampuan Berfikir Kritis Peserta Didik. Jurnal Pendidikan Kewarganegaraan, 2(2), 150-163. https://doi.org/10.31571/pkn.vli2.611

Niska, B., \& Gregorius, J. (2013). Penggunaan Media Poster Untuk Peningkatan Hasil Belajar Siswa Pada Pelajaran Pendidikan Kewarganegaraan di Sekolah Dasar. Jurnal Pendidikan Guru Sekolah Dasar, 1(2), 1-12.

Nurgiansah, T. H. (2019). Pemutakhiran Kurikulum Pendidikan Kewarganegaraan di Era Revolusi Industri 4.0. Prosiding Seminar Kewarganegaraan Universitas Negeri Medan, 1(1), 95-102.

Nurgiansah, T. H. (2020). Pelatihan Penulisan Artikel Ilmiah Bagi Mahasiswa PPKn Universitas PGRI Yogyakarta. JNPM: Jurnal Nasional Pengabdian Masyarakat, 1(1), 16-23.

Nurgiansah, T. H. (2021a). Pelatihan Penelitian Tindakan Kelas Bagi Guru Pendidikan Kewarganegaraan Di Sekolah Menengah Atas Se-Kabupaten Bantul. BERNAS: Jurnal Pengabdian Kepada Masyarakat, 2(1), 28-33. https://doi.org/10.31949/jb.v2i1.566

Nurgiansah, T. H. (2021b). Petuah Pendidikan Kewarganegaraan dalam Kontestasi Politik. AoEJ: Academy of Education Journal, 12(1), 39-47. https://doi.org/10.47200/aoej.v12i1.423

Nurgiansah, T. H., \& Pringgowijoyo, Y. (2020). Pelatihan Penggunaan Model Pembelajaran Jurisprudensial Pada Guru Di KB TK Surya Marta Yogyakarta. KUAT: Keuangan Umum dan Akuntansi Terapan. PKNSTAN, 2(1). https://doi.org/10.31092/kuat.v2i1.661

Nurgiansah, T. H., \& Sukmawati. (2020). Tantangan Guru Pendidikan Kewarganegaraan Di Masa Adaptasi Kebiasaan Baru. Jurpis: Jurnal Pendidikan Ilmu Sosial, 17(2), 139-149.

Rachman, F., \& Fitra, I. (2020). Kewarganegaraan dan Kesehatan: Partisipasi Warga dalam Penanganan Pandemi COVID-19 di Indonesia. Jurnal Ilmiah Pendidikan Pancasila dan Kewarganegaraan, 5(2), 289-303. https://doi.org/10.17977/um019v5i2p\%25p

Saffudin. (2013). Pengembagan E-learning Pendidikan Kewarganegaraan Berbasis Moodle di SMA Lampung Selatan. Jurnal Teknologi Informasi Komunikasi, 1(3), $1-12$.

Setiawan, D. (2014). Pendidikan Kewarganegaraan Berbasis Karakter melalui Penerapan Pendekatan Pembelajaran Aktif, Kreatif, Efektif dan Menyenangkan. Jurnal 
Pendidikan

Ilmu-Ilmu Sosial,

$6(2)$

$61-72$.

https://doi.org/10.24114/jupiis.v6i2.2285

Telaumbanua, F. (2019). Pembelajaran Pendidikan Pancasila dan Kewarganegaraan Berbasis E-Learning. Jurnal Warta Dharmawangsa, 6(2), 14-23. https://doi.org/10.46576/wdw.v0i62.503

Wibawa, I. M. A. J., \& Suarjana, I. M. (2019). Pengaruh Model Pembelajaran Kooperatif Tipe Jigsaw I dan Motivasi Belajar Terhadap Hasil Belajar Pendidikan Kewarganegaraan. Jurnal Ilmiah Sekolah Dasar, 3(1), 115-124. https://doi.org/10.23887/jisd.v3i1.17665 